\title{
Life-threatening Blood-Brain Barrier Disruption after Coiling of Unruptured Intracranial Aneurysm: Role of Immediate Postembolization CT scanning
}

\author{
Dong-Hun Kang, MD', Yong-Sun Kim, MD', Jaechan Park, MD²
}

We recently experienced a case of serious blood-brain barrier (BBB) disruption after coiling of unruptured intracranial aneurysm. The patient presented with an unruptured paraclinoid internal carotid artery (ICA) aneurysm on the right. Typical radiological, clinical characteristics were described. In addition, the role of immediate postembolization CT scan was also discussed.

Key Words : Aneurysm; Blood-brain barrier; Coil; Embolization

Nonionic iodinated contrast media $(\mathrm{CM})$ are generally used for diagnostic and interventional cerebral angiography. Several cases with minor complications resulting from nonionic $\mathrm{CM}$ have been reported (1-4). Regarding adverse events of CM, abnormal contrast enhancement have frequently been encountered up to $43 \%$ in clinical practices, and appearance of these patterns on CT scans can be various such as cortical, subarachnoid, intraventricular, and striatal enhancement $(5,6)$. Temporary disruption of bloodbrain barrier (BBB) permeability has been the primary explanation for such abnormal CT findings $(4,5,7)$. However, in most previous reports, abnormal enhancement after angiography had reported no symptoms, or mild transient symptoms. We have practiced immediate postembolization CT scans on every subject who

Departments of ${ }^{1}$ Neuroradiology and ${ }^{2}$ Neurosurgery, DaeguGyeongbuk Cardiocerebrovascular Center, Kyungpook National University, Daegu, Korea

Received December 18, 2009;

accepted after revision January 29, 2010.

Correspondence to: Yong-Sun Kim, MD, Department of Neuroradiology, Kyungpook National University, 50, Samduk-2-ga, Jung-gu, Daegu 700-721, Korea.

Tel. 82-53-420-5647 Fax. 82-53-423-0504

E-mail:knuhnr@hotmail.com

Neurointervention 2010;5:44-47 underwent neurointerventional treatment for the purpose of earlier detection of the aforementioned complications (5). Recently, we experienced a patient with BBB disruption who revealed typical radiological findings and simultaneously showed serious neurological deterioration.

\section{CASE REPORT}

A 58-year-old female patient was admitted for coiling of an unruptured paraclinoid internal carotid artery (ICA) aneurysm on the right. The coiling procedure was uneventful (Fig. 1A, B), and its duration was 80 minutes; $3.45 \mathrm{~cm}^{3} / \mathrm{Kg}$ of nonionic water-soluble iodinated contrast material (Visipaque 320; Amersham Health, Oslo, Norway) was used. The immediate postembolization CT scan showed strong hyperintensity within the sulci of the right frontoparietal lobe, and simultaneously showed high density in the right striatum with some gyral swelling (Fig. 1C, D). The patient was neurologically stable without headaches. At four hours following the procedure, she deteriorated neurologically to GCS 12 with left hemiparesis (4/5). MRI was performed immediately, and showed multiple small high signals on diffusion weighted image (DWI) in the right (Fig. 1E), which appeared to be caused by 
Serious Blood-Brain Barrier Disruption after Coiling

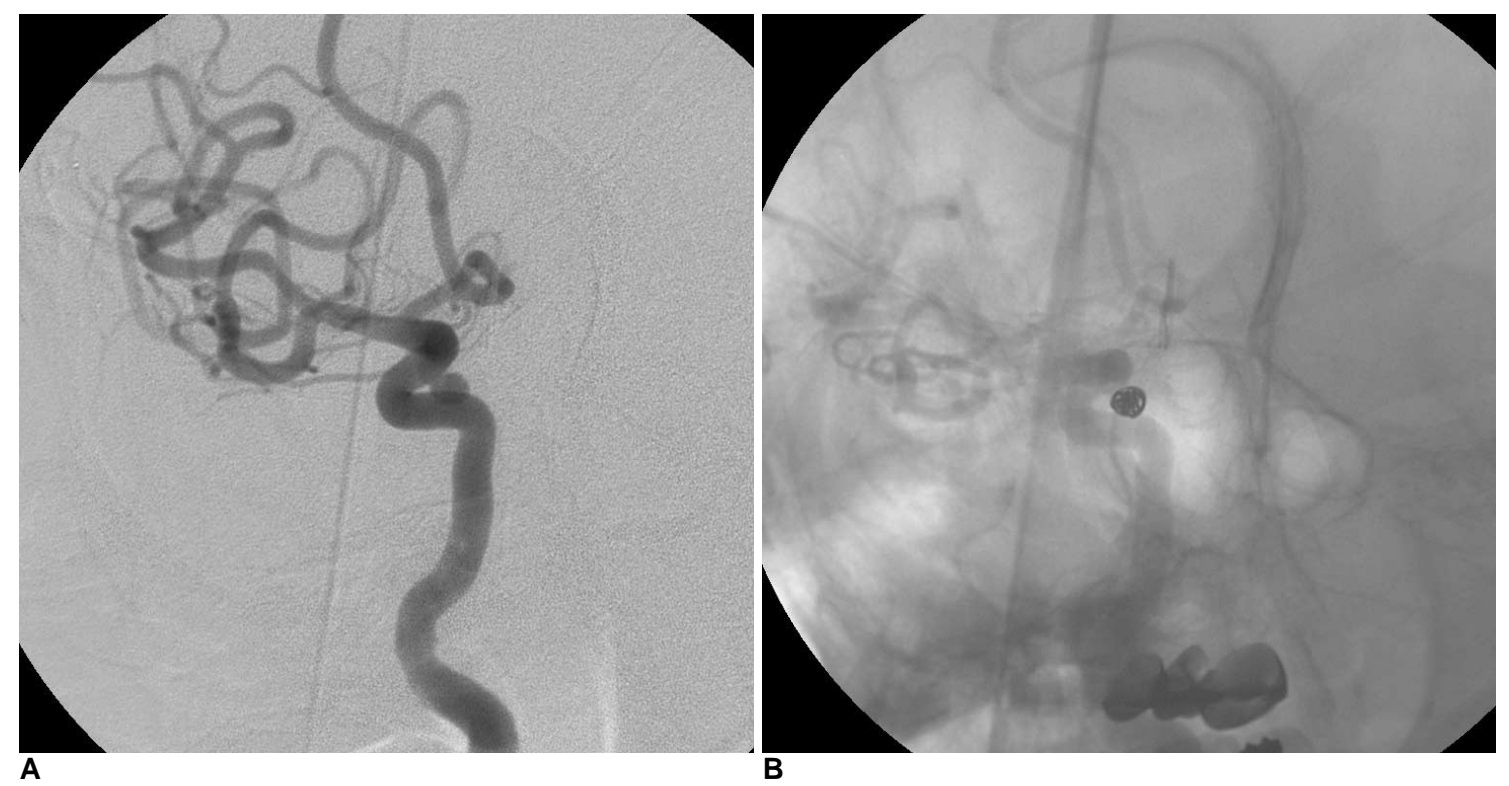

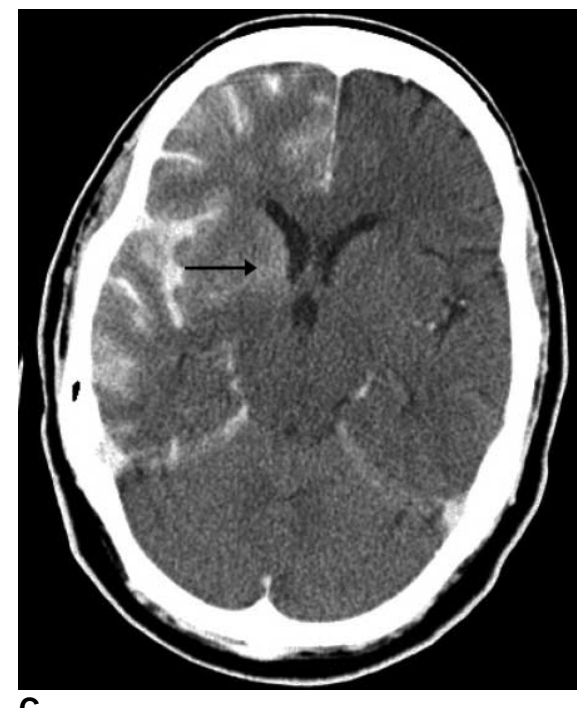

C

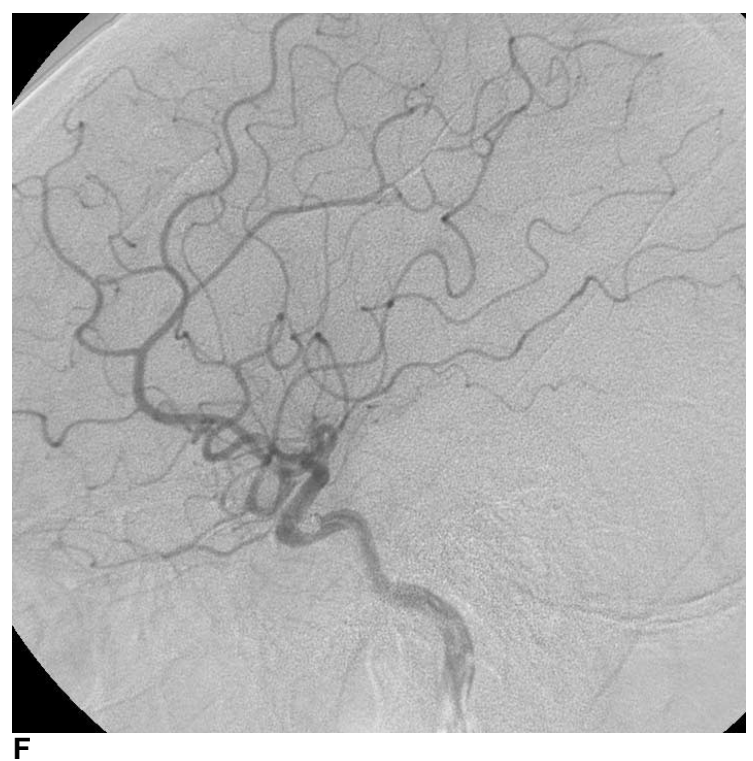

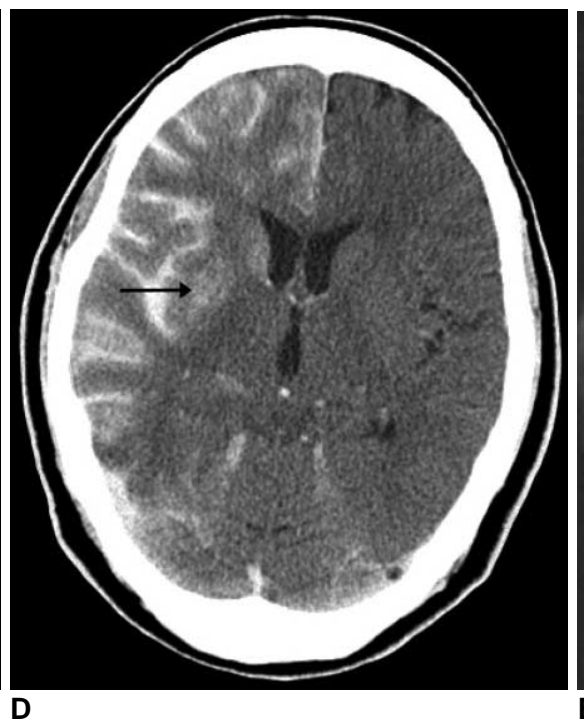

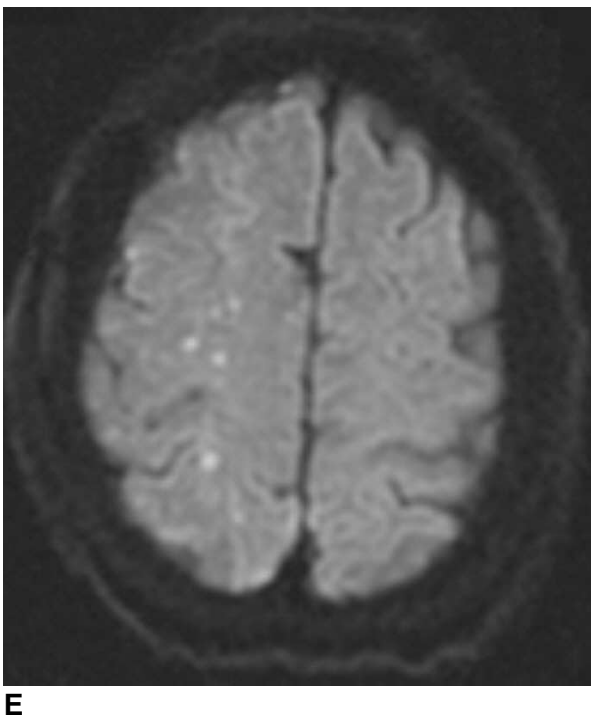

Fig. 1. A, B. procedural angiographic images show satisfactory embolization of the aneurysm.

C, D. immediate postembolization noncontrast CT scans are showing strong cortical hyperintensity of the right frontoparietal lobe and high density in the right striatum (arrow).

E. diffusion weighted image (DWI) MRI shows multiple small high signals in the right frontoparietal lobe.

F. digital subtraction angiography reveals diffuse narrowing of cortical branches of the MCA. 
microcatheter manipulation. She subsequently worsened neurologically to GCS 9 with left hemiparesis $(2 / 5)$. Digital subtraction angiography (DSA) followed; diffuse narrowing of cortical branches of the MCA and decrease of contrast flow velocity was demonstrated (Fig. 1F). We presumed that the patient's deterioration originated from $\mathrm{CM}$ induced BBB disruption rather than multiple microinfarctions. Thus, we limited systolic BP below 120 and monitored the patient in intensive care unit. The next day CT scan revealed no cortical hyperintensity with decreased gyral swelling. The patient showed neurological improvement 4 days after coiling and had recovered without deficit upon discharge.

\section{DISCUSSION}

Abnormal contrast enhancement on brain CT scan following diagnostic and interventional angiography has been reported. Transient disruption of BBB has been the main explanation for such findings (2, 4, 79). Various factors can induce temporary BBB disruption, including $\mathrm{CM}$, balloon inflation during remodeling technique, advanced age, and hypertension. Among these, iodinated CM has been regarded as the most constant and important factor influencing BBB permeability, and is known to be associated with osmolarity, chemical structure, and speed of injection of CM. Abnormal enhancement following CM induced BBB disruption has been mostly reported as clinically subtle, even symptomatic, the cases are not considered to be serious no more than transient global amnesia, cortical blindness, and seizure $(1-4,8)$. However, this study presented a case of life-threatening BBB disruption, which could have originated by the $\mathrm{CM}$, particularly after coiling of unruptured intracranial aneurysm.

Since January 2006, we have practiced immediate postembolization CT scanning for early detection of procedural complications including BBB disruption. We have reported $43 \%(46 / 61)$ of abnormal enhancement and four subtypes based on the CT findings (5). The present case of serious BBB disruption have provided us with clinical basis of immediate postembolization CT scanning. In the present case, we had trouble deciding on the cause of the patient's neurologic deterioration among several possible causative clues, including strong cortical hyperintensity on the right frontoparietal lobe and high density in the right striatum on postembolization CT scan, multiple microinfarctions on DWI, and diffuse narrowing of cortical branches of the MCA on follow-up DSA.
Without immediate postembolization CT scanning, we nearly missed the most important evidence for diagnosis of BBB disruption. According to a previous report, iodine contents in cerebrospinal fluid showed rapid decrease to near zero within two days (4). This patient also showed no contrast enhancement on next morning CT scans, which were performed at 15 hours after coiling.

In conclusion, this study presents a case of serious BBB disruption, which supposed to be caused by CM, particularly after coiling of unruptured intracranial aneurysm. Based on our experience, we suggest that BBB disruption should be considered in differential diagnosis under conditions of postembolization neurologic deterioration, although most abnormal enhancement on postembolization CT scan can be clinically subtle. In addition, we report on the clinical role of immediate postembolization CT scan with regard to early detection of such BBB disruptions.

\section{References}

1. Velden J, Milz P, Winkler F, Seelos K, Hamann GF. Nonionic contrast neurotoxicity after coronary angiography mimicking subarachnoid hemorrhage. Eur Neurol 2003;49:249-51

2. Mentzel HJ, Blume J, Malich A, Fitzek C, Reichenbach JR, Kaiser WA. Cortical blindness after contrast-enhanced CT: complication in a patient with diabetes insipidus. AJNR Am J Neuroradiol 2003;24:1114-16

3. Okazaki H, Tanaka K, Shishido T, Nagase H, Hoshino M, Takebayashi S, et al. Disruption of the blood-brain barrier caused by nonionic contrast medium used for abdominal angiography: CT demonstration. J Comput Assist Tomogr 1989;13:893-895

4. Uchiyama Y, Abe T, Hirohata M, Tanaka N, Kojima K, Nishimura $\mathrm{H}$, et al. Blood brain-barrier disruption of nonionic iodinated contrast medium following coil embolization of a ruptured intracerebral aneurysm. AJNR Am J Neuroradiol 2004;25:1783-1786

5. Baik SK, Kim YS, Lee HJ, Park J, Kim GC. Immediate CT findings following embolization of cerebral aneurysms: suggestion of blood-brain barrier or vascular permeability change. Neuroradiology 2008;50:259-266

6. Brisman JL, Jilani M, McKinney JS. Contrast enhancement hyperdensity after endovascular coiling of intracranial aneurysms. AJNR Am J Neuroradiol 2008;29:588-593

7. Uchiyama Y, Abe T, Tanaka N, Kojima K, Uchida M, Hirohata $\mathrm{M}$, et al. Factors contributing to blood-brain barrier disruption following intracarotid injection of nonionic iodinated contrast medium for cerebral angiography: experimental study in rabbits. Radiat Med 2006;24:321-326

8. May EF, Ling GS, Geyer CA, Jabbari B. Contrast agent overdose causing brain retention of contrast, seizures and Parkinsonism. Neurology 1993;43:836-88

9. Wilson AJ, Evill CA, Sage MR. Effects of nonionic contrast media on the blood-brain barrier. Osmolality versus chemotoxicity. Invest Radiol 1991;26:1091-1094 


\section{비파열성 뇌동맥류의 쿄일 색전술 후 발생한 심각한 혈뇌장벽 파기에 대한 증례 보고 및 색전술 직후 뇌전산화 단층 촬영의 임상적 의미}

1경북대학교 의과대학 경북대학교병원 영상의학과

${ }^{2}$ 경북대학교 의과대학 경북대학교병원 신경외과

\section{강동훈}

본원에서는 최근 우측 내경동맥의 비파열성 뇌동맥류의 성공적인 코일 색전술 이후 의식저하 및 좌측 반신 마비 가 발생한 환자를 치험하였다. 본 증례에서는 색전술 직후 시행한 뇌전산화 단층 촬영에서 혈뇌장벽 파괴로 판단 되는 특징적인 방사선학적 소견을 보였으며, 이후 심각한 수준의 신경학적 소견의 악화가 동반되었다. 이의 방사 선학적 소견 및 임상 경과를 보고하는 동시에 색전술 직후 뇌전산화 단층 촬영의 임상적 의미에 대하여 고찰하였 다.

Key Words : Aneurysm; Blood-brain barrier; Coil; Embolization 